\title{
Guru Kreatif dalam Mengembangkan Alat Permainan Edukatif untuk Anak Usia Dini di TK Pamardi Siwi Depok Sleman
}

\author{
Aniyawati ${ }^{1}$ \\ STAI Al Ma'arif Way Kanan ${ }^{1}$, Indonesia, \\ Aniyawati29@gmail.com
}

\begin{abstract}
This study aims to determine the creative teacher in developing educational play tools for early childhood in kindergarten Pamardi Siwi Depok Sleman. This type of research is qualitative, which is a research process that is conducted naturally and naturally according to conditions in the field without objective data manipulation or information. And the type of data collected prioritizes qualitative data. Data collection techniques in this study are observation, interviews and documentation, data analysis techniques using data reduction, data presentation, conclusions. The results of this study are based on the characteristics of creative teachers that researchers have done and have done observations and interviews, the researchers concluded that the teachers at TK Pamardi Siwi Depok Sleman from the three teachers at TK Pamardi Siwi who have the characteristics of creative teachers only Mrs. NR Creativity products for the development of educational games that have been made by NR are webbing, colorful circles, sewing, touch cities, animal dwellings, colorful circles, cubes, arranging tower shapes with colorful glasses, picture cards and letter cards, shapes geometric shapes.
\end{abstract}

Keywords:

Creative teacher; Educational games tools;

Early childhood.

\section{Abstrak}

Penelitian ini bertujuan untuk mengetahui guru kreatif dalam mengembangkan alat permainan edukatif untuk anak usia dini di TK Pamardi Siwi Depok Sleman. Jenis penelitian ini adalah kualitatif yaitu suatu proses penelitian yang dilakukan secara wajar dan natural sesuai kondisi yang ada objektif dilapangan tanpa ada manipulasi data atau inforamasi serta jenis data yang dikumpulkan diutamakan data kualitatif. Teknik pengumpulan data dalam penelitian ini yaitu observasi,

\section{Kata Kunci:}

Guru kreatif;

Alat permainan

edukatif;

Anak usia dini. 
wawancara dan dokumentasi, teknik analisis data menggunakan reduksi data, penyajian data, simpulan. Hasil penelitian ini berdasarkan dari ciri-ciri guru kreatif yang peneliti lakukan dan sudah melakukan observasi dan wawancara maka peneliti menyimpulkan bahwa guru-guru yang ada di TK Pamardi Siwi Depok Sleman dari ketiga guru yang ada di TK Pamardi Siwi yang memiliki ciri-ciri guru kreatif hanyalah ibu N.R. Produk kreativitas pengembangan alat permainan edukatif yang telah dibuat ibu N.R adalah anyaman, bulatan warna warni, menjahit, kotak raba, tempat hidup binatang, bulatan warna-warni, kubus, menyusun bentuk menara dengan gelas warna-warni, kartu gambar dan kartu huruf, bentuk-bentuk geometri.

Diterima : 17 November; Direvisi: 09 Januari; Diterbitkan: 25 Februari

http://doi.org/10.19105/kiddo.v2i1.4147

\section{Pendahuluan}

Guru yang kreatif membuat semangat belajar siswa akan meningkat dengan sumber belajar beragam, alat peraga yang menarik juga media yang mendukung dan sesuai. Sumber belajar dikaitkan dengan tema dan subtema pada hari itu misalnya untuk belajar tema tanaman dengan subtema bagian tanaman dan fungsinya guru harus berfikir sumber apa yang menarik. Menurut Manispal ( 2018:214-215) inilah kenapa guru PAUD harus rajin, kreatif dan inovatif. Tidak mudah menyediakan pembelajaran yang menarik tanpa usaha perlu kerja keras untuk membuat pembelajaran menjadi menarik dan menyenangkan perlu kreativitas dan inovasi untuk membuat alat peraga yang menarik dan disukai untuk mewujudkan terlaksanaya proses pembelajaran yang menarik dan menyenangkan. Proses kreatif tahapan persiapan ketika idividu mengumpulkan informasi untuk memecahkan masalah. Individu memikirkan penyelesaian masalah yang dihadapinya. Guru yang kreatif untuk pendidik anak usia dini sangat penting guru yang kreatif.

Manispal (2018:31) alasan mengapa guru harus kreatif karena anak usia dini tengah tumbuh dan berkembang serba ingin tahu suka berimajinasi, berkhayal, berimprovisasi, berargumentasi, menjelajah dan mencoba. Mereka butuh guru yang memfasilitasi dan minimnya media dan sumber belajar yang tersedia di taman kanak-kanak/PAUD yang terbatas sehingga guru perlu mencari dan memperkaya lingkungan. Anak membutuhkan panutan cara berfikir dan sikap kreatif. Hampir semua komponen lingkungan membutuhkan peran guru untuk mengelola dan mengoprasikannya menjadi pengalaman kreatif bagi anak. 


\section{Metode}

Jenis penelitian yang digunakan dalam penelitian ini adalah penelitian penelitian kualitatif. Penelitian kualitatif adalah penelitian yang mengembangkan secara sistematis menggunakan fakta-fakta yang ada yang ditemukan dilapangan baik bersifat verbal, kalimatkalimat, fenomena dan tidak berupa angka. Kirl dan Miller menyatakan bahwa penelitian kualitatif adalah tradisi tertentu dalam ilmu pengetahuan sosial (social science) yang secara fundamental bergantung pada pengamatan manusia dalam kawasanya sendiri dan berkenaan dengan orang-orang tersebut dalam bahasannya dan dalam peristilahannya.

Teknik pengumpulan data yang akan digunakan dalam penelitian studi kasus ini adalah wawancara, observasi dan analisis dokumen. Menurut Arikuto (2012:44) wawancara adalah suatu cara atau metode yang digunakan untuk mendapatkan jawaban dari responden dengan tanya jawab sepihak, dapat dikatakan tanya jawab sepihak karena responden tidak diberi kesempatan untuk mengajukan pertanyaan. Pertanyaan hanya dapat dilakukan oleh pewawancara. Menurut Putra (2013:226) sedangkan observasi atau biasa disebut dengan pengamatan, observasi ini menggunakan jenis observasi non partisan, pengamat (observer) tidak ikut dalam kegiatan orang yang diobservasi 30 teknik ini dilakukan peneliti untuk memperoleh data yang berkaitan dengan pemasaran jasa pendidikan di lembaga sekolah tersebut. Selanjutnya analisis dokumen ialah peneliti akan mengumpulkan sejumlah dokumen yang berhubungan dengan penelitian ini yang kemudian dianalisis untuk memperdalam, dan memperinci temuantemuan penelitian.

\section{Hasil dan Pembahasan}

Menurut Salirawati dan Nur Syamsiah (2018:62-72) guru yang kreatif dan inovasi adalah guru yang mampu mengembangakan kegiatan yang beragam didalam dan diluar kelas menggunakan alat bantu, media sederhana yang dapat dibuat sendiri oleh guru atau peserta didinya mengajak peserta didik bereksperimen berdasarkan berbagai kejadian di sekitar dalam kegiatan yang menarik dan ilmiah dengan menggunakan bahan serta alat dalam kehidupan sehari-hari. Guru yang menciptakan permainan dan memberikan selingan dalam belajar yang masih berkaitan dengan konsep yang di ajarkan pada hari itu yang termasuk guru kreatif. Das Salirawati(2018:70-71 ) kreatif adalah cara berfikir yang mengajak kita keluar dan melepaskan diri dari pola umum yang melekat pada ingatanmu. Beberapa hal yang yang mampu mengembangakan pikiran kita menjadi kreatif antara lain berfantasi atau mengemukakan ide atau gagasan yang tidak umum terkesan nyeleneh berada pada satu gagasan atau ide berani mengambil resiko, peka terhadap segala keajaiban penasaran 
terhadap suatu kebenaran serta banyak membaca artikel penemuan yang membuat kagum dan terheran-heran.

Beetlestone menyatakan bahwa kreatif berarti melibatkan pengungkapan gagasan dan perasaan serta penggunaan berbagai macam cara untuk menemukan, mengeksplorasi, dan mencari kepastian untuk menyelesaikan suatu permasalahan. Seseorang yang kreatif melihat sesuatu yang sama tetapi melalui cara berpikir berbeda. Menurut pendapat Ngalim dan Fhadilah (2013:44) Terdapat dua ciri mengenai cara berfikir kreatif menurut Guilford yaitu cara berfikir konvergen, merupakan cara-cara individu dalam memikirkan sesuatu dengan pandangan bahwa hanya ada satu jawaban yang benar. Dan ciri cara berfikir selanjutnya ialah berfikir divergen, ialah kemampuan individu untuk mencari alternatif jawaban terhadap sebuah persoalan.

Ciri-ciri guru kreatif dan sosok seorang guru yang kreatif adalah sebagai berikut, selalu tertarik pada sesuatu yang baru untuk disuguhkan pada anak, gemar mencoba otak atik benda untuk menemukan sesuatu yang baru dan menantang untuk dipecahkan anak, senang terhadap ide atau gagasan baru, memiliki kemampuan berfikir dan sikap kreatif menyuguhkan pembelajaran jadi lebih hidup, lebih menarik, lebih menantang sehingga anak-anak mau mencoba, menjelajahi dan melakukannya.

Mengembangkan kreativitas guru PAUD memang sebagian besar TK/PAUD di Indonesia tidak berorientasi pada kreativitas tetapi semata terfokus baca, tulis dan hitung. TK/PAUD yang berorientasi pengembangan kreativitas direncanakan secara sistematis yang diimplimentasikan dalam berbagai kegiatan pembelajaran kreatif dan dibimbing dan dilatih oleh guru kreatif. Manispal (2018:126) di lembaga PAUD/TK faktor penentu tumbuh dan berkembangnya kreativitas anak terletak pada guru selain karena sarana dan prasarana, media dan kekayaan sumber belajar yang disediakan sekolah. Guru yang membimbing anak usia dini harus sosok yang kreatif. Guru harus belajar dan berusaha menjadikan dirinya kreatif. Guru harus mampu mengembangkan pembelajaran berorentasi kreatif. Menjadi guru kreatif guru bisa kreatif karena usaha, kegemaran, kepedulian dan komitmen tinggi terhadap tugas dan kecintaannya terhadap pekerjaannya. Guru kreatif tidak tergantung dari tingkat pendidikannya tetapi lebih pada motivasi dan usaha untuk memperkenalkan sesuatu yang baru unik, menarik dan menantang sehingga anak terpacu mengikuti.

Berfikir dan bersikap kreatif setiap guru bisa menjadi kreatif tergantung dari kecintaan terhadap pekerjaannya dan komitmen untuk meyuguhkan sesuatu yang baru menarik dan menantang. Guru kreatif tampak dari cara berfikir dan sikap kreatifnya. Untuk mengembangkan cara berfikir kreatif guru harus secara kontinu membaca banyak literatur semisal ensiklopedia, buku sains dan produk kreatif. Buku 
dapat memunculkan ide kreatif di samping menumbuhkan rasa ingin tahu untuk mencoba sampai mencipta produk kreatif sendiri.

Cara berfikir kreatif juga ditunjukkan oleh kemampuan tinggi dalam memecahkan masalah. Guru kreatif lebih tahan frustasi atas kegagalan baik terhadap masalah pribadi, anak atau pembelajaran sampai menciptakan jalan keluar baru. Manispal (2018:317:38) Guru kreatif cendrung mengabaikan hal-hal sepele yang tidak perlu enggan membuang-buang waktu terhadap hal-hal kecil dan setia terhadap tujuannya untuk memenuhi kebutuhan belajar anak didik. Guru kreatif selalu tertantang menciptakan sesuatu yang dapat membuat anak gembira dan antusias. Sikap kreatif guru ditunjukan dari unjuk kerjanya.

Kreativitas guru dalam mengemas pembelajaran yang menarik, menyenangkan tetapi menantang anak agar terlibat aktif membutuhkan kreativitas. Ini berarti setiap hari guru PAUD berupaya menemukan ide-ide baru untuk membuat pembelajaran tetap menarik, menyenangkan, bermakna sekaligus menantang bagi anak. Anak usia dini senang dan semangat terhadap situasi baru pola interaksi baru dalam pembelajaran. Urutan pembelajaran yang sama setiap hari bisa membuat anak jenuh karena itu guru perlu membuat kreasi baru. Tidak penting urutannya tetapi tema yang disampaikan bermakna bagi anak. Ubahlah metode pembelajaran agar lebih variasi gaya mengajar dan penciptaan suasana kelas. Mengemas pembelajaran yang menyenangkan asik dan menarik adalah keharusan bagi guru anak usia dini.

Anak usia dini dengan karakteristik suka bergerak, aktif dan selalu tertarik hal baru membutuhkan pembelajaran aktif. Minat kegemaran keingintahuan anak dapat dikembangkan dalam pembelajaran aktif. Pentingnya bagi guru untuk selalu mengembangkan pembelajaran aktif hanya dengan itu proses kreativitas anak dapat berkembang. Manispal (2018:318-319) Kreativitas sulit berkembang dalam pembelajaran yang monoton, menakutkan, memaksakan dan menjenuhkan. Sekali lagi kunci utama membangun proses berpikir kreatif anak usia dini adalah dengan mengemaskan pembelajaran aktif, asyik, menarik dan menyenangkan.

Kreativitas guru dalam menyediakan sumber belajar yang beragam. Sumber belajar yang banyak dan beragam sangat dibutuhkan untuk merasang tumbuhnya kreativitas anak. Anak usia dini tidak suka pembelajaran dengan hanya duduk diam, tangan dilipat mata melotot ke depan. Mereka suka eksplorasi, bergerak, aktif, serba ingin tahu, mata, telinga, tangan selalu bergerak dan sangat tertarik jika pembelajaran disajikan dengan benda yang sebenarnya (konkret) bukan abstrak, sumber belajar beragam sangat membantu guru dalam menyajikan pembelajaran kreatif.

Sumber belajar dan alat peraga tidak perlu selalu membeli kreatif dapat memanfaatkan lingkungan sekitar. Daun, akar, batu, belalang, 
kepiting sawah ulat dapat menjadi sumber belajar yang menarik. Koran bekas, kertas semen, caking telur, biji lengkeng dapat menjadi media pembelajaran. Daun kering misalnya dapat dijadikan bahan membuat rambut dalam sketsa wajah orang atau sebagai bulu untuk gambar burung. Gambar dari koran bekas dapat digunting dan anak diminta untuk menjelaskan apa yang terjadi baik lisan maupun tulisan (meskipun tulisan anak belum jelas) koran juga bisa dilipat untuk membuat rambut, perahu, bola, robot dan seterusnya. Manispal (2018:126) guru di wilayah pegunungan, pantai atau pedalaman bisa kreatif memanfaatkan media dan sumber belajar di alam yang sangat beragam sehingga tidak perlu membeli di kota seperti kertas karton, krayon atau cat. Cat misalnya dapat dibuat dari tepung kanji, biji alpukat, cangkang telur, lumpur.

Guru bisa kreatif karena usaha, kegemaran, kepedulian dan komitmen tinggi terhadap tugas dan kecintaannya terhadap pekerjaannya. Guru kreatif tidak tergantung dari tingkat pendidikannya tetapi lebih pada motivasi dan usaha untuk memperkenalkan sesuatu yang baru unik, menarik dan menantang sehingga anak terpacu mengikuti.

Kemalawati (2017:7-9) dalam mengemukakan bahwa Alat Permainan Edukatif (APE) adalah alat permainan yang sengaja dirancang secara khusus untuk kepentingan pendidikan. Contohnya permainan balok yang berbagai macam bentuk seperti kubus, kotak, kotak raba, puzzle. Pengertian pengembangan alat permainan edukatif adalah suatu cara atau proses atau perbuatan menjadikan sempurna definisi ini mengandung makna bahwa dalam pengembangan terhadap proses menyempurnakan suatu produk tertentu sehingga memiliki manfaat atau kegunaan yang lebih baik dari sebelumnya. Proses pembuatan maupun pengembangan alat permainan edukatif ini dapat dilakukan melalui cara ATM yakni amati, tiru dan modifikasi. Fhadillah (2018:122-123) selain itu yang patut menjadi perhatian ialah dalam pengembangan ini harus ada tambahan nilai kegunaan bukan sebaliknya pengurangan nilai kegunaanya sehingga lebih bermanfaat bagi pertumbuhan dan perkembangan anak. Penggunaan alat permainan edukatif untuk anak usia dini pada saat pembelajaran dapat mendukung perkembangan anak sehingga tujuan pembelajaran dapat tercapai. Menurut Purnama (2019:61-62) yang di kutip dari Gardner sebagaimana dikutip Mulyasa anak usia dini memegang peranan yang sangat penting karena perkembangan otak manusia saat dilahirkan ke dunia anak manusia telah mencapai perkembangan otak $25 \%$ sampai usia 4 (empat tahun) perkembangannya mencapai $50 \%$ dan sampai 8 (delapan) tahun mencapai $80 \%$ selebihnya berkembang sampai usia 18 (delapan belas) tahun. Oleh karenanya pada masa usia dini harus betul-betul dimanfaatkan dengan sebaik-baiknya untuk memberikan pendidikan sebagai sarana menstimulus dan mengembangkan 
kecerdasan majemuk anak. Adapun permainannya anak yang sangat efektif adalah dengan menggunakan alat permainan edukatif.

Desain alat permainan edukatif anak usia dini adalah desain tidak semata-mata rancangan di atas kertas tetapi juga proses secara keseluruhan sampai karya tersebut terwujud dan memiliki nilai. Desain merupakan aktivitas praktis yang meliputi unsur ekonomi, sosial, teknologi, dan budaya dalam berbagai dinamikanya. Dalam konteks ini desain yang dimaksud adalah produk merupakan salah satu bidang keilmuan yang terintergrasi dengan segala bentuk aspek kehidupan manusia dari masa ke masa.

Tujuan pengemabangan edukatif APE terdapat beberapa tujuan yang ingin dicapai adalah untuk menambah nila guna, untuk menambah kuantitas, untuk perbaikan alat permainan edukatif, untuk peningkatan kreativitas, untuk melestarikan alat permainan edukatif. Prinsip-prinsip pengembangan alat permainan edukatif dalam pengembangan alat permainan edukatif ada beberapa prinsip yang harus diperhatikan oleh pengembangan supaya alat permainan edukatif yang dihasilkan dapat berfungsi dengan optimal. Fahdilah (2019:83-86) prinsip-prinsip yang dimaksud adalah sebagai berikut: prinsip bahan, prinsip bentuk, prinsip warna, prinsip manfaat, prinsip kebutuhan sesuai dengan kebutuhan anak, mendukung kegiatan aktif, bersifat terbuka, memberi banyak tujuan, aman dan awat, memiliki duplikasi, non gender dan rasis (alat permainan yang tidak membedakan anak perempuan dan laki-laki atau ras tertentu).

Adapun ciri-ciri APE bagi anak yaitu ditujukan pada anak-anak usia dini, selalu dirancang dengan pemikiran yang mendalam disesuaikan dengan rentang usia anak. APE untuk anak rentang usia 4-5 tahun tentu berbeda dengan APE untuk anak rentang usia 5-6 tahun contohnya: puzzel. Puzzel untuk anak usia 4-5 tahun memiliki bentuk sederhana dengan potongan yang tidak terlalu banyak kepingannya. Jumlah kepingan puzzle untuk anak usia 5-6 tahun, lebih banyak lagi. Jadi memang APE dirancang untuk rentang usia tertentu. Syamsudi (2012:60-61) Berfungsi untuk mengembangkan aspek-aspek perkembangan anak TK, aspek-aspek yang dapat dikembangkan adalah aspek fisik (motorik halus dan kasar), emosi, sosial, bahasa, kognitif, dan moral. APE yang dirancang untuk mengembangkan aspek kognitif biasanya dapat digunakan untuk melatih daya nalar anak, dapat digunakan dengan berbagai cara, bentuk dan multi guna aman bagi anak dapat mendorong aktifitas dan kreativitasanak dan bersifat konstruktif. Syafri (2013:301) Hal ini juga dijelaskan bahwa setiap alat permainan edukatif dapat difungsikan secara multi guna. Sekalipun masing-masing memiliki kekhususan, dalam mengembangkan aspek perkembangan tertentu pada anak tidak jarang satu alat dapat meningkatkan lebih dari satu aspek perkembangan alat permainan edukatif selalu dirancang dengan pemikiran yang mendalam, karena melalui bermain alat tersebut, anak 
mampu mengembangkan penalarannya. Edukatif standar pengembangan APE merupakan batasan-batasan yang diperbolehkan atau diizinkan. Dalam kaitanya dengan pengembangan alat permainan edukatif.

Standarisasi ini untuk memberikan keamanan bagi setiap pengguna baik dalam waktu singkat ataupun lama. Fhadillah (2019:129) Di Indonesia sekarang ini telah diberlakukan SNI (Standard Nasional Indonesia) untuk mainan anak sebagaimana telah dikeluarkannya peraturan pemerintah nomor 102 tahun 200 standardisasi Nasional Peraturan Menteri Nomor 55/M-IND/PER/112013 tentang perubahan Peraturan Menteri Perindustrian Nomor 24/M-IND/4/2013tentang pemberlakuan SNI secara wajib dan Peraturan Direktur Jendral Basis Industri Manufaktor Nomor 09/BIM/PER/1/2014 petunjuk teknis pelaksanaan pemberlakuan dan pengawasan penerapan SNI mainan secara wajib. Dengan adanya peraturan tersebut maka setiap orang yang membuat maupun menjual alat permainan harur lolos uji SNI. Apabila tidak lolos uji SNI maka alat permainan dilarang beredar dan digunakan anak. Namun yang perlu dipahami pemberlakuan SNI ini dikhususkan bagi para produsen yang ingin memproduksi alat permainan secara masal dan menjualnya kemasyarakat luas. Jika hanya membuat dalam jumlah terbatas dan untuk keluarga sendiri maka tidak wajib untuk mendaftarkan produk mainnya ke SNI.Yang penting mainanya aman digunakan anak.

Fathurrahmah (2017:408-416) tujuan pendidikan anak usia dini yang ingin dicapai adalah untuk mengembangkan pengetahuan dan pemahaman orangtua dan guru serta pihak-pihak yang terkait dengan pendidikan dan perkembangan anak usia dini. Sementara menurut $\mathrm{J}$. Piaget dalam Wiryasumarta memaparkan bahwa pelajaran yang diberikan lewat permainan akan lebih menarik dan menyenangkan hati anak sehingga hasilnya akan lebih baik, sementara Montessori mengartikan kegiatan bermain sebagai latihan jiwa dan badan demi kehidupan anak dimasa datang. Nugroho (2015:285-286) ciptakan lingkungan yang kondusif dalam hal ini, pendidikan di usia dini memerlukan pengkondisian lingkungan yang mendorong munculnya kreativitas anak. Lingkungan pendidikan harus menyediakan lingkungan belajar yang kaya akan simulasi imajinatif, seperti pemandangan, suara, tekstur, bentuk, objek dan hal-hal lainnya yang bersifat abstrak. Oleh karena itu guru PAUD harus menyediakan lingkungan yang imajinatif, veriatif dan kreatif.

Menuru Sawyers (2015:13) kurikulum yang sesuai dengan perkembangan anak usia dini, dan kenali dan optimalkan peluang untuk memfasilitasi potensi kreatif sepanjang hari. Artinya, tafsirkan panduan kurikulum untuk memfasilitasi eksplorasi, bermain, dan potensi kreatif. Interpretasi semacam itu melibatkan guru yang berperan aktif dalam proses kreatif. 
Menurut Fahturohmah (2007: 408-4016) tujuan pendidikan anak usia dini yang ingin dicapai adalah untuk mengembangkan pengetahuan dan pemahaman orangtua dan guru serta pihak-pihak yang terkait dengan pendidikan dan perkembangan anak usia dini. Sementara menurut J. Piaget dalam Wiryasumarta memaparkan bahwa pelajaran yang diberikan lewat permainan akan lebih menarik dan menyenangkan hati anak sehingga hasilnya akan lebih baik, sementara Montessori mengartikan kegiatan bermain sebagai latihan jiwa dan badan demi kehidupan anak dimasa datang. Berbagai permainan yang dilakukan anak merupakan latihan atas tugas dan fungsi yang akan dijalani di waktu yang akan datang. Menurut Nugroho (2025:285-386) ciptakan lingkungan yang kondusif dalam hal ini, pendidikan di usia dini memerlukan pengkondisian lingkungan yang mendorong munculnya kreativitas anak. Lingkungan pendidikan harus menyediakan lingkungan belajar yang kaya akan simulasi imajinatif, seperti pemandangan, suara, tekstur, bentuk, objek dan hal-hal lainnya yang bersifat abstrak. Oleh karena itu guru PAUD harus menyediakan lingkungan yang imajinatif, variatif dan kreatif.

Penemuan atau pembelajaran berbasis inkuiri, kurikulum konstruktivis berbasis pengalaman dan pengembang sekutu praktik yang sesuai dalam pendidikan anak usia dini menyediakan model untuk mengajar anak-anak di mana bermain dan kreativitas adalah bagian integral. Menurut Taganoy, ide-ide yang disajikan di sini tidak dimaksudkan untuk merevolusi kurikulum anak usia dini. Menurut Deborah W. Tegano James D. Moran Janet K. Sawyers(2005:3) Sebagai gantinya, pesannya mungkin: Ambil apa yang kita ketahui adalah kurikulum yang sesuai dengan perkembangan anak usia dini, dan kenali dan optimalkan peluang untuk memfasilitasi potensi kreatif sepanjang hari. Artinya, tafsirkan panduan kurikulum untuk memfasilitasi eksplorasi, bermain, dan potensi kreatif. Interpretasi semacam itu melibatkan guru yang berperan aktif dalam proses kreatif.

Guru yang kreatif dan inovasi adalah guru yang mampu mengembangkan kegiatan yang beragam didalam dan diluar kelas menggunakan alat bantu, media sederhana yang dapat dibuat sendiri oleh guru atau peserta didinya mengajak peserta didik bereksperimen berdasarkan berbagai kejadian di sekitar dalam kegiatan yang menarik dan ilmiah dengan menggunakan bahan serta alat dalam kehidupan sehari-hari.

Produk kreativitas yang dimaksud disini adalah produk kreativitas atau pengembangan alat permainan edukatif yang dibuat sendiri oleh guru. Pengembangan alat permainan edukatif adalah suatu cara atau proses atau perbuatan menjadikan sempurna definisi ini mengandung makna bahwa dalam pengembangan terhadap proses menyempurnakan suatu produk tertentu sehingga memiliki manfaat atau kegunaan yang lebih baik dari sebelumnya. 
Ciri-ciri sosok seorang guru yang kreatif adalah sebagai berikut selalu tertarik pada sesuatu yang baru untuk disuguhkan pada anak, gemar mencoba otak-atik benda untuk menemukan sesuatu yang baru dan menantang untuk dipecahkan anak, senang terhadap ide atau gagasan baru, memiliki kemampuan berfikir dan sikap kreatif menyuguhkan pembelajaran jadi lebih hidup, lebih menarik, lebih menantang sehingga anak-anak mau mencoba, menjelajahi dan melakukannya.

Berdasarkan dari ciri-ciri guru kreatif diatas setelah peneliti melakukan observasi dan wawancara maka peneliti menyimpulkan bahwa guru-guru yang ada di TK Pamardi Siwi Depok Sleman dari ketiga guru yang ada di TK Pamardi Siwi yang memiliki ciri-ciri guru kreatif hanyalah ibu N.R.

Sumber atau inspirasi dalam membuat produk kreativitas guru kreatif dalam mengembangkan alat permainan edukatif dari pelatihan atau seminar yang di adakan pemerintah untuk meningkatkan guru kreatif, membaca buku aspek perkembangan, pertemuan ikatan guru taman kanak-kanan dan kelompok kerja guru gugus taman kanakkanan karena di setiap pertemuan pasti ada hal-hal baru yang didapatkan seperti pembuatan alat permainan edukatif dari sekolah lain, pengalaman-pengalaman dari rekan sesama guru dalam mengembangkan alat permainan edukatif dan memanfaatkan teknologi yang sudah maju bisa mencari inspirasi sumber-sumber media sosial seperti youtobe dan yang lainnya.

Hasil Wawancara N.R (2020:23) ibu N.R mulai membuat alat permainan edukatif sejak diangkat menjadi pegawai negeri sipil yaitu pada tahun 2008 awalnya dalam membuat alat permainan edukatif untuk pengembangan potensi diri dan membuat laporan seiring dengan berjalanya waktu ibu N.R menjiwai dalam membuat alat permainan edukatif dan lebih tertarik lagi dan lagi membuat, selalu tentang untung membuat alat permainan edukatif yang baru untuk disuguhkan kepada anak dan suka terhadap ide atau gagasan baru. Hasil wawancara R.W (2020:23) Ibu R.W tidak membuat alat permainan edukatif dikarenakan dengan faktor umur selain itu karena sudah tidak bisa lagi untuk naik pangkat dan ibu R.W memanfaatkan alat permainan edukatif yang disedikan oleh sekolah.

Hasil Wawancara (2020:23) Ibu E.Y tidak membuat alat permainan edukatif karena selain karena faktor umur dan karena sebagai guru honor yang tidak bisa lagi menjadi pegawai negeri sipil. ibu E.Y memanfaatkan alat permainan edukatif dari sarana prasarana yang di sediakan sekolah.

Berdasarkan wawancara dan observasi yang dilakukan peneliti dapat disimpulkan bahwa dari ketiga guru yang ada di TK Pamardi Siwi Depok Sleman yang mengembangkan alat permainan edukatif hanyalah ibu N.R dan guru yang lain memanfaat alat permainan edukatif dari sarana prasaran yang disedikan sekolah. Produk 
kreativitas pengembangan alat permainan edukatif yang telah dibuat ibu N.R adalah sebagai berikut anyaman, bulatan warna warni, menjahit, kotak raba, tempat hidup binatang, bulatan warna-warni, kubus, menyusun bentuk menara dengan gelas warna-warni, kartu gambar dan kartu huruf, bentuk-bentuk geometri.

\section{Kesimpulan}

Berdasarkan wawancara dan observasi yang telah dilakukan didaptkan dari ketiga guru yang ada di TK Pamardi Siwi Depok Sleman di peroleh yang memiliki ciri-ciri guru kreatif yaitu ibu N.R.

Berdasarkan pengamatan dan hasil wawancara yang telah dilakukan peneliti dapat di simpulkan dari ketiga guru yang ada di TK Pamardi Siwi Depok Sleman, yang mengembangkan produk kreativitas yaitu yang berupa mengembangkan alat permainan edukatif untuk anak usia dini yaiti ibu N.R. beberapa alat permainan yang telah dibuat oleh ibu N.R yaitu anyaman, bulatan warna warni, menjahit, kota raba, tempat hidup binatang, bulatan warna-warni, kubus, menyusun bentuk menara dengan gelas warna-warni, kartu gambar dan kartu huruf, bentuk-bentuk geometri.

\section{Daftar Pustaka}

Arikunto, Suharsimi. (2012). Dasar-Dasar Evaluasi Pendidikan. Cet Ke 6: Bumi Aksara.

Fathurrohman, Amang. (2017). Rintisan Pendidikan Anak Usia Dini Suku Tengger Di Wilayah Terpencil Dusun Surorowo Desa Kayukebek Kecamatan Tutur Kabupaten Pasuruan. In Proceedings: Annual Conference For Muslim Scholar.

Ika Kemalawati.(2017). Upaya Meningkatkan Kreativitas Anak Melalui Alat Permainan Balok Di Taman Kanak-Kanak Cipta Mulia Kecamatan Cipatat Kabupaten Bandung Barat. Empowerment 6, No. 1.

M Fadlillah. (2018), Bermain Dan Permainan Anak Usia Dini. Jakarta: Prenadamedia Grup.

Masnipa.(2018). Menjadi Guru Paud Professional. Bandung: Pt Remaja Rosdakarya.

Ngalimun, (2013). Haris Fadillah, Alpha Ariani. Perkembangan Dan Pengembangan Kreativitas. Yogyakarta: Aswaja Pressindo, 2013.

Nugroho, Puspo.(2015). Pandangan Kognitifisme Dan Aplikasinya Dalam Pembelajaran Pendidikan Agama Islam Anak Usia Dini. Thufula 3, No. 2.

Nusa Putra. (2015). Metode Penelitian Kualitatif Pendidikan. Jakarta: Raja Grafindo Persada.

Salirawati, (2018). Das. Smart Teaching Solusi Menjadi Guru 
Professional. Jakarta: Bumi Aksara.

Sawyers, (2005). Creativity In Early Childhood Classrooms. September: Library Of Congress Cataloging-In-Publication Data.

Sigit Purnama, (2019). Alat Permainan Edukatif Anak Usia Dini. Bandung: PT Remaja Rosdakarya.

Syafri, Fatrica. (2013). Urgensi Pemilihan Alat Permainan Edukatif (Ape) (Studi Pada Guru Taman Kanak-Kanak Witri I Kota Bengkulu). At-Ta'lim 12, No. 2.

Syamsiyah, Salirawati \& Nur. (2018). Smart Teaching Solusi Menjadi Guru Kreatif. Jakarta: Bumi Aksara.

Syamsuardi. (2012). Penggunaan Alat Permainan Edukatif (APE) Di Taman Kanak-anak PAUD Polewali kecamatan Taneteriattang Barat kabupaten Bone. Publikasi pendidikan 11, No. 1. 